\title{
Anosmia as a clinical predictor to non-fatal COVID-19 case and better survivability
}

\author{
Anosmia como prediitor clínico do caso COVID-19 não fatal e melhor sobrevida
}

Anosmia como predictor clínico del caso de COVID-19 no fatal y una mejor supervivencia

I Gede Purna Weisnawa

ORCID: https://orcid.org/0000-0001-5895-8340 Medical Faculty Udayana University, Indonesia E-mail: deigaweisnawa@gmail.com

Ni Made Susilawathi

ORCID: https://orcid.org/0000-0002-3166-2440 Medical Faculty Udayana University, Indonesia

E-mail: susilawathi@unud.ac.id

Cokorda Agung Wahyu Purnamasidhi ORCID: https://orcid.org/0000-0002-1646-3793 Medical Faculty Udayana University, Indonesia E-mail: purnamasidhi@unud.ac.id

Giovanca Verentzia Purnama ORCID: https://orcid.org/0000-0002-5470-6098 Medical Faculty Udayana University, Indonesia E-mail: giovancaver@gmail.com

I Komang Hotra Adiputra ORCID: https://orcid.org/0000-0002-5922-4127 Medical Faculty Udayana University, Indonesia E-mail: hotraadiputra@gmail.com

Richard Christian Suteja ORCID: https://orcid.org/0000-0001-7649-0913 Medical Faculty Udayana University, Indonesia E-mail: richardcs88@gmail.com

Jerry

ORCID: https://orcid.org/0000-0002-3822-0119 Medical Faculty Udayana University, Indonesia E-mail: chen7jerry@gmail.com

Putu Kintan Wulandari ORCID: https://orcid.org/0000-0002-8172-3061 Medical Faculty Udayana University, Indonesia E-mail: kntnwulandari@gmail.com

\begin{abstract}
Recently, a respiratory infectious disease labeled as COVID-19 caused by SARS-CoV-2 had taken over the world by storm. This RNA virus can cause various symptoms such as malaise, anosmia, ageusia, fever, cough, headache, myalgia, diarrhea, and ARDS. COVID-19 patients have specific symptoms such as fever. In another study, it was said that anosmia could be a benchmark for screening for COVID-19. in a study of young patients and was more common in women. The average onset of anosmia occurs on day 4 after infection and lasts for 8 days. the evidence says that this disease can cause a decrease in a person's quality of life. The exact cause of anosmia is still unknown, but several theories suggest that anosmia can occur due to damage to nerve receptors, inflammation of olfactory epithelial cells, and dysfunction of nerve receptors. The popular theory is that anosmia occurs due to inflammation of the olfactory epithelial cells, thereby damaging the olfactory receptors. The inflammation blocks odors from reaching the nasal mucosa and can inhibit receptor excitability and signal transduction. Anosmia may be associated with lower hospital mortality rates. However, further research and discovery is needed to fully grasp the pathophysiological concept of COVID-19 induced anosmia. This review will discuss the pathophysiology and review the lower anosmia mortality rate. This article reviews current understandings about the pathophysiology of anosmia and its potential as a marker towards better clinical prognosis. This narrative review aims to provide knowledge about updates regarding the pathophysiology of anosmia as a clinical predictor of mild and severe COVID-19 symptoms.
\end{abstract}

Keywords: Anosmia; Pathophysiology; Mortality; COVID-19. 


\begin{abstract}
Resumo
COVID-19 é uma doença infecciosa respiratória causada pelo SARS-CoV-2. Este vírus de RNA pode causar vários sintomas, como mal-estar, anosmia, ageusia, febre, tosse, dor de cabeça, mialgia, diarreia e SDRA. Os pacientes com COVID-19 apresentam sintomas específicos, como febre. Em outro estudo, foi dito que a anosmia poderia ser uma referência para o rastreamento do COVID-19. em um estudo com pacientes jovens e foi mais comum em mulheres. O início médio da anosmia ocorre no $4^{\circ}$ dia após a infecção e dura 8 dias. as evidências dizem que essa doença pode causar diminuição na qualidade de vida de uma pessoa. A causa exata da anosmia ainda é desconhecida, mas várias teorias sugerem que a anosmia pode ocorrer devido a danos aos receptores nervosos, inflamação das células epiteliais olfatórias e disfunção dos receptores nervosos. A teoria popular é que a anosmia ocorre devido à inflamação das células epiteliais olfatórias, danificando os receptores olfatórios. A inflamação impede que os odores atinjam a mucosa nasal e pode inibir a excitabilidade do receptor e a transdução do sinal. Anosmia pode estar associada a taxas de mortalidade hospitalar mais baixas. No entanto, pesquisas adicionais são necessárias para compreender a fisiopatologia da anosmia e a mortalidade observada. Esta revisão irá discutir a fisiopatologia e revisar a menor taxa de mortalidade por anosmia. Neste artigo, discutiremos a fisiopatologia da anosmia, e a anosmia está associada a uma menor mortalidade hospitalar. Esta revisão narrativa tem como objetivo fornecer conhecimento sobre as atualizações a respeito da fisiopatologia da anosmia como um preditor clínico de sintomas leves e graves de COVID-19.
\end{abstract}

Palavras-chave: Anosmia; Fisiopatologia; Mortalidade; COVID-19.

\title{
Resumen
}

COVID-19 es una enfermedad infecciosa respiratoria causada por el SARS-CoV-2. Este virus de ARN puede causar varios síntomas como malestar, anosmia, ageusia, fiebre, tos, dolor de cabeza, mialgia, diarrea y SDRA. Los pacientes con COVID-19 tienen síntomas específicos como fiebre. En otro estudio, se dijo que la anosmia podría ser un punto de referencia para la detección de COVID-19. en un estudio de pacientes jóvenes y fue más común en mujeres. El inicio promedio de la anosmia ocurre el día 4 después de la infección y dura 8 días. la evidencia dice que esta enfermedad puede causar una disminución en la calidad de vida de una persona. La causa exacta de la anosmia aún se desconoce, pero varias teorías sugieren que la anosmia puede ocurrir debido a daños en los receptores nerviosos, inflamación de las células epiteliales olfativas y disfunción de los receptores nerviosos. La teoría popular es que la anosmia se produce debido a la inflamación de las células epiteliales olfativas, lo que daña los receptores olfatorios. La inflamación impide que los olores lleguen a la mucosa nasal y puede inhibir la excitabilidad del receptor y la transducción de señales. La anosmia puede estar asociada con menores tasas de mortalidad hospitalaria. Sin embargo, se necesitan más investigaciones para comprender la fisiopatología de la anosmia y la mortalidad observada. Esta revisión discutirá la fisiopatología y revisará la menor tasa de mortalidad por anosmia. En este artículo, discutiremos la fisiopatología de la anosmia, y la anosmia se asocia con una menor mortalidad hospitalaria. Esta revisión narrativa tiene como objetivo proporcionar conocimientos sobre actualizaciones con respecto a la fisiopatología de la anosmia como un predictor clínico de síntomas de COVID-19 leves y graves.

Palabras clave: Anosmia; Fisiopatología; Mortalidad; COVID-19.

\section{Introduction}

In December 2019, a respiratory infectious disease later labeled as COVID-19 caused by SARS-CoV-2 had taken over the world by storm (Cascella et al., 2021; Singhal, 2020). Though its origins were not completely known, phylogenetical research reported SARS-CoV-2 as a coronavirus mutant to those often found to infect bats (Cascella et al., 2021; Singhal, 2020). Not long after, the virus reportedly triggered outbreaks in neighboring countries (Singhal, 2020; Yuki et al., 2020).

Symptoms that caused by COVID-19 vary widely, Ranging from malaise, anosmia, ageusia, cough, fever, headache, myalgia, arthralgia, diarrhea, up to sepsis, septic shock, and Acute Respiratory Distress Syndrome (ARDS) (Cascella et al., 2021; Guan et al., 2020; Klopfenstein et al., 2020; WHO, 2021). The majority of people infected with COVID-19 experience nonspecific symptoms. But in vulnerable groups such as the elderly, the symptoms caused can have a worse impact. In the elderly and/or populations with congenital diseases, COVID-19 can cause symptoms such as pneumonia, ARDS, to multiple organ dysfunction (MODS) so it can increase the risk of death (Guan et al., 2020; Singhal, 2020). Therefore, rapid screening is needed to detect someone infected with COVID-19. So far, fever has always been associated with COVID-19 and has been used as a benchmark for COVID-19 screening. However, according to another study, the assessment using anosmia for COVID-19 screening is better than temperature (Butowt \& Bartheld, 2020). 
Anosmia is an olfactory dysfunction which causes a decrease in the power of smell. Anosmia can occur suddenly at the time of initial infection with COVID-19 with or without symptoms. Anosmia usually occurs accompanied by ageusia, dry cough and fever (Meng et al., 2020). The onset of anosmia is average 4.4 days after infection with COVID-19 and lasts about 8 days (Klopfenstein et al., 2020). There are several possible theories about the cause of anosmia, but the exact cause of anosmia is still unknown. Some of these theories, among others: first, damage to olfactory neuron receptors. Third, there is infiltration in the brain that affects the olfactory center which causes olfactory neuron receptor dysfunction. Finally, damage to the support cells of the olfactory epithelium (Butowt \& Bartheld, 2020).

\section{Methodology}

This is a narrative review about anosmia as a clinical predictor for severe and mild COVID-19 covering studies from 2020 and 2021. The keywords for this review are Covid-19, anosmia, pathophysiology, and mortality.

\section{Smelling Physiology and Anosmia}

Human gather information and analyzing the surroundings by olfactory system, the main sense for perception of odors, along with auditory and vision (Nef, 1998). An odor molecule called odorant were inhaled and dissolve in mucus produced by bowman glands (Heidari et al., 2020). The odorant then bind to many different types of G-protein coupled receptors at the cribriform plate (Branigan \& Tadi, 2021). These binding then activated cyclic adenosine monophosphate (cAMP) that will open the ion channel of sodium and calcium in neuron plasma (Branigan \& Tadi, 2021). An action potential then occurred and undergo through glomeruli in the olfactory bulb. The stimulus will be carried and processed in the specific areas of the brain, which include the olfactory tubercle, piriform cortex, entorhinal cortex, and amygdala (Branigan \& Tadi, 2021; Nef, 1998).

If the odorant receptors in nasal epithelium were damaged or the neuron system suffered from neurodegenerative disease, people may experience anosmia or loss of smell (Boesveldt et al., 2017). Anosmia may further cause the loss of gustatoric senses and lowers the quality of life (Boesveldt et al., 2017). Pusswald et al (2012) also found anosmia had negative impacts on patient's pleasure of food, mood, personal hygiene, matters of safety, even their sexual activity (Pusswald et al., 2012). In a research by Elkholi et al. (2021), 76\% from 487 COVID-19 patients who experienced anosmia had decreased quality of life (Elkholi et al., 2021) These patients are also being less aware about their environment as they are unable to smell smoke, rotten food, and dangerous gases which may be hazardous to the patient (Elkholi et al., 2021).

\section{Anosmia in COVID-19}

Anosmia induced by SARS-CoV-2 infection is called COVID-19 induced anosmia (Meng et al., 2020). In clinical setting, anosmia is a highly specific sign of COVID-19, even patients can only experience anosmia without any other symptoms (Heidari et al., 2020; Meng et al., 2020). Studies done in Italy, Spain, UK, France, Belgium, US and Iran reported that the incidence of anosmia in COVID-19 patient varies between $33.9 \%$ to $68 \%$, with numbers being higher in females compared to males (Meng et al., 2020).

Google trends also showed a skyrocketed number in search of olfactory disorders during pandemic (A et al., 2020; SB et al., 2020). There are studies using golden Syrian hamsters that have been infected with COVID-19. Biopsy analyzed from nasal mucose showed severe damage in olfactory epitheliums at 3 days post-infection, with gradual recovery 5 to 10 days postinfection, followed by full recovery of the nasal mucose 21 days post-infection (Urata et al., 2021). 


\section{Pathophysiology Anosmia in COVID-19}

Though there hasn't been a consensus within health experts about the pathophysiology underlying this clinical manifestation, there has been two popular opinions about how the manifestation came about (da Silva Júnior et al., 2021).

Zou et al. looked for hACE-2 expression within various cells in the body from scRNA-seq datasets with reference to hACE-2 expressing alveolar type II cells (Zou et al., 2020). More than 2\% cells (compared to 1\% of AT2 cells) sampled from respiratory tract expresses hACE-2, which makes it a susceptible site of infection (Zou et al., 2020). Direct binding to these receptors may induce degeneration and inflammation, thereby causing damage to olfactory receptors (Whitcroft \& Hummel, 2020). If not due to the damage, inflammation may mechanically obstruct odors from reaching nasal mucosa, inhibiting receptor excitement and further signal transduction (Lao et al., 2020). This theory is proven by a normal olfactory bulb and neurons shown in MRI scan of an anosmic patient (MK et al., 2020).

Researches also found that hACE-2 are also expressed in glial cells of the CNS and spinal neurons (Ahmad \& Rathore, 2020). Viremia fever disrupts the selective permeable blood-brain barrier, allowing leakages and the virus to enter the CNS and inducing meningitis (Ahmad \& Rathore, 2020; Naz et al., 2020). This meningitis may disrupt how the brain perceive odor, possibly causing hyposmia or anosmia (Ahmad \& Rathore, 2020; Lao et al., 2020). This theory is widely accepted most likely due to how SARS-CoV-2 is related and similar to SARS-CoV, this theory has been proven on mice (Whitcroft \& Hummel, 2020). In Italy, a research found that anosmic patients were strongly associated with fever but no nasal obstruction nor rhinitis, thus indicating that there were likely no direct damages towards epithelial olfactory nerves (Vaira et al., 2020). It is highly possible that these two mechanisms do occur interchangeably and cause the same olfactory manifestation. However, further research must be done to test both of these theories; and if both are true, which of these two is the most prevalent. Identification of prevalent pathomechanism may help designate definitive and symptomatic intervention. About $72.6 \%$ of patients in these study regained their smelling and gustatory function within the first 8 days, which possibly suggests that majority of COVID-19 induced anosmia may be only temporary (Lechien et al., 2020).

\section{Anosmia Associated with Lower Hospital Mortality}

Patients with anosmia sometimes do not realize that they are sick. A meta-analysis article by Purja et al (2021) said that patients with anosmia had a low chance of being hospitalized. In the study of Klopfenstein et al. Of the 114 COVID-19 patients, 54 (47\%) patients experienced anosmia. From these data, it was found that $85 \%$ of patients had dysgeusia. Of these 54 patients, they had a low Charlson comorbidity index, with common symptoms such as asthma, arterial hypertension, and cardiovascular disease. Results of this study, patients with anosmia were found to have a high recovery rate (Klopfenstein et al., 2020). In a study by Blanca et al, anosmia was common in COVID-19 patients. Of the 576. patients who met the study criteria, a total of $146(25.3 \%)$ patients experienced anosmia. In this study, 5 (3.4\%) of 146 patients with anosmia died. This study shows that anosmia has a relatively low mortality rate. Upon entering the session, the robot says "Hello" to the child. This greeting scenario has been developed to provide emotional interaction (Spain et al., 2015; Saadatzi et al., 2018). The robot, at the same time as greeting the child, shakes their hand accordingly to show that it greets them.

\section{Conclusion}

Anosmia is the appearance of olfactory dysfunction that causes a decrease in the power of smell. Young female patients are known to be more common with anosmia. While the exact cause is not yet to be known, the most popular causes of anosmia can occur due to direct viral entry into the CNS and disruption of the olfactory nerve receptors. 
Anosmia may be associated with less severe clinical manifestations and lower mortality rate in confirmed COVID-19 patients. Several research articles have found that patients with anosmia are more likely to be discharged from the hospital than patients with severe symptoms. Currently, there is no known cause of how severe anosmia can lead to death. Anosmia is one of the symptoms that indicate this is a mild COVID-19 infection, but that doesn't mean it doesn't appear in severe cases.

\section{Reference}

A, W., C, H., \& P, S. (2020). Use of Google Trends to investigate loss-of-smell-related searches during the COVID-19 outbreak. International Forum of Allergy \& Rhinology, 10(7), 839-847. https://doi.org/10.1002/ALR.22580

Ahmad, I., \& Rathore, F. A. (2020). Neurological manifestations and complications of COVID-19: A literature review. Journal of Clinical Neuroscience, 77, 8-12. https://doi.org/10.1016/J.JOCN.2020.05.017

Boesveldt, S., Postma, E. M., Boak, D., Welge-Luessen, A., Schöpf, V., Mainland, J. D., Martens, J., Ngai, J., \& Duffy, V. B. (2017). Anosmia—A Clinical Review. Chemical Senses, 42(7), 513. https://doi.org/10.1093/CHEMSE/BJX025

Branigan, B., \& Tadi, P. (2021). Physiology, Olfactory. StatPearls.

Butowt, R., \& Bartheld, C. S. von. (2020). Anosmia in COVID-19: Underlying Mechanisms and Assessment of an Olfactory Route to Brain Infection. The Neuroscientist. https://doi.org/10.1177/1073858420956905

Cascella, M., Rajnik, M., Aleem, A., Dulebohn, S. C., \& Napoli, R. Di. (2021). Features, Evaluation, and Treatment of Coronavirus (COVID-19). StatPearls.

da Silva Júnior, P. R., Gomes, A. L. O. R., Coelho, L. E. A., Morais, M. A., de Almeida, P. V. F. C., Neri, W. J. R., Mascena, G. V., \& de Farias Leal, A. A. (2021). Anosmia and COVID-19: perspectives on its association and the pathophysiological mechanisms involved. The Egyptian Journal of Neurology, Psychiatry and Neurosurgery. 57:1, 57(1), 1-8. https://doi.org/10.1186/S41983-020-00266-0

Elkholi, S. M. A., Abdelwahab, M. K., \& Abdelhafeez, M. (2021). Impact of the smell loss on the quality of life and adopted coping strategies in COVID-19 patients. European Archives of Oto-Rhino-Laryngology. 278:9, 278(9), 3307-3314. https://doi.org/10.1007/S00405-020-06575-7

Guan, W., Ni, Z., Hu, Y., Liang, W., Ou, C., He, J., Liu, L., Shan, H., Lei, C., Hui, D. S. C., Du, B., Li, L., Zeng, G., Yuen, K.-Y., Chen, R., Tang, C., Wang, T., Chen, P., Xiang, J., ... Zhong, N. (2020). Clinical Characteristics of Coronavirus Disease 2019 in China. Https://Doi.Org/10.1056/NEJMoa2002032, 382(18), 1708-1720. https://doi.org/10.1056/NEJMOA2002032

Heidari, Karimi, Firouzifar, Khamushian, Ansari, Ardehali, M., \& Heidari. (2020). Anosmia as a prominent symptom of COVID-19 infection. Rhinology, 58(3), 302-303. https://doi.org/10.4193/RHIN20.140

Klopfenstein, T., Kadiane-Oussou, N. J., Toko, L., Royer, P.-Y., Lepiller, Q., Gendrin, V., \& Zayet, S. (2020). Features of anosmia in COVID-19. Medecine et Maladies Infectieuses, 50(5), 436. https://doi.org/10.1016/J.MEDMAL.2020.04.006

Lao, W. P., Imam, S. A., \& Nguyen, S. A. (2020). Anosmia, hyposmia, and dysgeusia as indicators for positive SARS-CoV-2 infection. World Journal of Otorhinolaryngology - Head and Neck Surgery, 6(Suppl 1), S22. https://doi.org/10.1016/J.WJORL.2020.04.001

Lechien, J. R., Chiesa-Estomba, C. M., De Siati, D. R., Horoi, M., Le Bon, S. D., Rodriguez, A., Dequanter, D., Blecic, S., El Afia, F., Distinguin, L., ChekkouryIdrissi, Y., Hans, S., Delgado, I. L., Calvo-Henriquez, C., Lavigne, P., Falanga, C., Barillari, M. R., Cammaroto, G., Khalife, M., ... Saussez, S. (2020). Olfactory and gustatory dysfunctions as a clinical presentation of mild-to-moderate forms of the coronavirus disease (COVID-19): a multicenter European study. European Archives of Oto-Rhino-Laryngology. 277:8, 277(8), 2251-61. https://doi.org/10.1007/S00405-020-05965-1

Li, X., \& Lui, F. (2021). Anosmia. The Journal of Laryngology, Rhinology, and Otology, 15(11), 579-81.

Meng, X., Deng, Y., Dai, Z., \& Meng, Z. (2020). COVID-19 and anosmia: A review based on up-to-date knowledge. American Journal of Otolaryngology, 41(5), 102581. https://doi.org/10.1016/J.AMJOTO.2020.102581

MK, G., J, G., M, B., AS, N., \& S, H. (2020). Olfactory Bulb Magnetic Resonance Imaging in SARS-CoV-2-Induced Anosmia: The First Report. Academic Radiology, 27(6), 892-893. https://doi.org/10.1016/J.ACRA.2020.04.002

Naz, S., Hanif, M., Haider, M. A., Ali, M. J., Ahmed, M. U., \& Saleem, S. (2020). Meningitis as an Initial Presentation of COVID-19: A Case Report. Frontiers in Public Health, 8, 474. https://doi.org/10.3389/FPUBH.2020.00474

Nef, P. (1998). How we smell: The molecular and cellular bases of olfaction. News in Physiological Sciences, 13(February 1998), 1-5. https://doi.org/10.1152/physiologyonline.1998.13.1.1

Pusswald, G., Auff, E., \& Lehrner, J. (2012). Development of a brief self-report inventory to measure olfactory dysfunction and quality of life in patients with problems with the sense of smell. Chemosensory Perception, 5(3-4), 292-299. https://doi.org/10.1007/S12078-012-9127-7

SB, G., C, K., \& C, H. (2020). Isolated sudden onset anosmia in COVID-19 infection. A novel syndrome? Rhinology, 58(3), 299-301, https://doi.org/10.4193/RHIN20.114

Singhal, T. (2020). A Review of Coronavirus Disease-2019 (COVID-19). Indian Journal of Pediatrics, 87(4), 281. https://doi.org/10.1007/S12098-020-032636 
Research, Society and Development, v. 12, n. 2, e14811224661, 2022

(CC BY 4.0) | ISSN 2525-3409 | DOI: http://dx.doi.org/10.33448/rsd-v11i2.24661

Urata, Maruyama, Kishimoto-Urata, Sattler, Cook, Lin, Yamasoba, Makishima, \& Paessler. (2021). Regeneration Profiles of Olfactory Epithelium after SARSCoV-2 Infection in Golden Syrian Hamsters. ACS Chemical Neuroscience, 12(4). https://doi.org/10.1021/ACSCHEMNEURO.0C00649

Vaira, L. A., Salzano, G., Deiana, G., \& Riu, G. De. (2020). Anosmia and Ageusia: Common Findings in COVID-19 Patients. The Laryngoscope, $130(7), 1787$. https://doi.org/10.1002/LARY.28692

Whitcroft, K. L., \& Hummel, T. (2020). Olfactory Dysfunction in COVID-19: Diagnosis and Management. JAMA, 323(24), 2512-2514. https://doi.org/10.1001/JAMA.2020.8391

WHO. (2021). Coronavirus. WHO.

Yuki, K., Fujiogi, M., \& Koutsogiannaki, S. (2020). COVID-19 pathophysiology: A review. Clinical Immunology (Orlando, Fla.), $215,108427$. https://doi.org/10.1016/J.CLIM.2020.108427

Zou, X., Chen, K., Zou, J., Han, P., Hao, J., \& Han, Z. (2020). Single-cell RNA-seq data analysis on the receptor ACE2 expression reveals the potential risk of different human organs vulnerable to 2019-nCoV infection. Frontiers of Medicine, 14(2), 185-192. https://doi.org/10.1007/s11684-020-0754-0 